\title{
Observational analysis of the variability of actions in judo: the key for success?
}

\author{
Marcus Fábio AGOSTINHO ${ }^{* 1,2}$ (D) \& Emerson FRANCHINI 1 (iD) \\ ${ }_{1}^{1}$ Martial Arts and Combat Sports Research Group, School of Physical Education and Sport, \\ University of São Paulo (Brazil) \\ ${ }^{2}$ Faculdade Lusófona de São Paulo (Brazil)
}

Received: 16/10/2020; Accepted: 17/01/2021; Published: 19/01/2021.

\begin{abstract}
The main objective of the present study was to determine whether variation in gripping action, actions before attacking, throwing techniques, direction of attack, transition from standing to groundwork combat, and groundwork techniques varied between male and female judo athletes and between gold, silver and bronze medalists in judo World Championships for cadet, junior and senior athletes. Therefore, 296 athletes who won medals in these competitions between 2018 and 2019, who executed a total of 1202 scoring actions in standing position and 300 scoring actions in the groundwork combat were analyzed. Higher variation was observed for gold medal winners for grip actions before attack compared to bronze medalists, whereas transition variation was greater for gold medal winners compared to the other medalists. However, no differences were found between age groups, except when interacting with sex, as a lower technique variation was observed in female cadets compared to all other male age groups. Additionally, less variation was observed in females compared to males for grip, actions before attacking, number of techniques and direction of attacks. Therefore, variation in some elements can properly discriminate the podium position, females present less variation than males, but no relevant differences were found between age groups.
\end{abstract}

ORIGINAL PAPER

Keywords: Martial arts; combat sports; variation; technique; tactics; long-term athlete development.

\section{Análisis observacional de la variabilidad de acciones en judo: ¿la clave del éxito? \\ Resumen}

El objetivo principal del presente estudio fue determinar si la variabilidad en la acción de agarre, acciones antes de atacar, técnicas de proyección, dirección de ataque, transición combate de pie a suelo, y técnicas de judo suelo, diferían entre judokas masculinos y femeninos, y entre medallistas de oro, plata y bronce en los Campeonatos del Mundo de judo en las categorías cadete, junior y senior. Se analizaron 296 judokas que ganaron medallas en esta competición entre 2018 y 2019, los cuales ejecutaron un total de 1202 acciones puntuables en posición de pie y 300 acciones puntuables en suelo. Se observó una mayor variabilidad en los ganadores de medallas de oro en agarre y acciones antes del ataque, en comparación con los medallistas de bronce, mientras que la variabilidad de transición combate de pie a suelo fue mayor para los ganadores de medallas de oro en comparación con el resto de medallistas. Sin embargo, no se encontraron diferencias entre los grupos de edad, excepto en su interacción con el sexo, encontrando una menor variabilidad de técnicas en las mujeres cadetes en comparación con todos los demás grupos de edad masculinos. Además, se observó una menor variabilidad en las mujeres en comparación con los hombres en cuanto a agarre, acciones antes de atacar, número de técnicas y dirección de los ataques. Por lo tanto, la variabilidad en algunos elementos puede discriminar adecuadamente la posición alcanzada en el podio, las

\section{Análise observacional da variabilidade das ações no judô: a chave para o sucesso? \\ Resumo}

O objetivo principal do presente estudo foi determinar se a variação nas formas de pegada, ações antes de atacar, técnicas de projeção, direções de ataque, formas de transição do combate em pé para o combate no solo e técnicas de domínio variavam entre atletas de judô dos sexos masculino e feminino e entre medalhistas de ouro, prata e bronze nos Campeonatos Mundiais de judô das classes Sub-18, Sub-21 e Sênior. Para isso, foram analisados 296 atletas que conquistaram medalhas nestas competições em 2018 e 2019, os quais geraram 1202 pontuações no combate em pé e 300 pontuações no combate de solo. Foi observada maior variação entre os medalhistas de ouro para pegada e ações antes de atacar quando comparados aos medalhistas de bronze, enquanto a variação de transição foi maior para os medalhistas de ouro em comparação com os demais medalhistas. Contudo, não foram verificadas diferenças entre as faixas etárias, exceto na interação com o sexo, sendo observada menor variação de técnicas de projeção nas medalhistas Sub-18 em comparação com todas as outras classes etárias do masculino. Adicionalmente, as atletas apresentaram menor variação em comparação com os atletas para pegada, ações antes de atacar, técnicas de projeção e direções de ataque. Portanto, a variação em determinados elementos técnicos pode discriminar adequadamente o resultado competitivo, sendo que

*E-mail: maagostinho@hotmail.com 
mujeres presentan menor variabilidad que los hombres, y no se encontraron diferencias relevantes entre grupos de edad.

Palabras clave: Artes marciales; deportes de combate; variación; técnica; táctica; desarrollo del atleta a largo plazo. atletas do sexo feminino apresentam menor variação do que atletas do masculino, mas não foram verificadas diferenças relevantes entre as faixas etárias.

Palavras-chave: Artes marciais; esportes de combate; variação; técnica; tática; desenvolvimento em longo prazo.

\section{Introduction}

Judo is a grappling combat sport in which athletes compete in different weight categories and age groups. The main competitions in this sport are the Olympic Games and the World Championship, where athletes older than 15 years-old can take part, although competitors' ages are $24.9 \pm 3.9$ years for female and 25.4 \pm 3.8 years for male athletes (Franchini et al., 2020). Furthermore, for those who are younger, age-specific competitions exist such as the Youth Olympic Games for those under 18 years-old and the World Championships for cadets (under 18 years-old), and juniors (under 21 years-old).

During judo matches, athletes engage in different actions, with the following being the most frequently executed (Franchini et al., 2013): (a) displacement without contact - after the referee signal to start or restart the match, athletes approach each other to dominate the grip. This phase lasts 4-6s per sequence of combat (time between hajime, command to start, and matte, command to stop the match) and demands high attention levels, but low-physical effort, as no contact is yet in place; (b) grip dispute - each athlete tries to impose his/her grip dominance over the opponent, which is a key element to execute a throwing technique. This phase lasts $15-20$ s per sequence of combat and is the longest action executed during the match, demanding high levels of strength-endurance, especially for upper-body muscles; (c) throwing technique execution - this type of technique is the main scoring action in judo, lasting around 1s per execution and demanding high levels of muscle power from both lower and upper-body muscles; (d) standing to groundwork transition - in judo, athletes can score using immobilization, strangle and elbow joint-lock techniques, but the transition from standing to groundwork position determines the actions in groundwork. This phase lasts less than 10s per sequence of combat and demands both muscle power and strength-endurance; (e) groundwork - in this phase athletes try to execute an immobilization, strangle or elbow joint-lock technique to score. This phase can last a few seconds, when the referee notices that no relevant actions are being performed, up to around 30-40s when a sequence of relevant actions is performed. Therefore, the physical demands vary considerably in this phase; and (f) pause - breaks are imposed by the referee when athletes leave the combat area or execute an action resulting in a penalty. During this phase athletes try to recover from the previous efforts, whereas listening to their coaches' instructions, as this is the only phase during the match when the coach can talk to their athletes. This phase typically lasts around 5-10s per sequence.

Previous publications indicated that a high variability of actions can be important for the athlete to become less predictable and increase the chance of scoring during judo matches. Indeed, Franchini et al. (2008) reported that super-elite judo athletes (i.e., those winning the Olympic Games and World Championships at least once and winning another additional medal in these competitions) executed a higher number of throwing techniques and to more directions from the same grip position compared with elite judo athletes (i.e., athletes winning more than one medal in Olympics or World Championships, although not being gold medalists). However, these athletes did not differ in terms of groundwork techniques. Furthermore, there were no sexes differences for number of techniques (throwing and groundwork) and directions of throws. A more recent study (Camargo et al., 2019) analyzed the direction of attacks in judo athletes taking part in the 2017 Senior World Championship, and indicated that throwing techniques resulting in scores were executed similarly to the four directions, with no variation between sexes, weight categories and competition phases, suggesting that athletes at this competition level do not specialize in attacks for a single direction. However, an investigation analyzing the throwing techniques used during this competition (Martins et al., 2019) reported that the ten most used throwing techniques resulted in more than half of all scoring actions. When the grip dispute is considered, higher level athletes present higher variability of actions and faster changes between phases from the first approach to the two hands grip configuration and the 
throwing technique execution than beginners and intermediate level athletes (Calmet et al., 2010). Therefore, a higher variation of actions to perform a grip and faster changes between actions, a larger variability when executing throwing techniques and more direction of attacks are important aspects for the highest level of achievement in this sport, but typically most of the athletes score using one of 11 techniques (i.e., seoi-nage, o-uchi-gari, uchi-mata, ko-uchi-gari, ippon-seoi-nage, ko-soto-gake, sode-tsurikomi-goshi, sumi-otoshi, o-soto-gari, sumi-gaeshi, and tai-otoshi).

However, few studies analyzed these aspects in different age groups. Indeed, only Calmet and Ahmaidi (2004) reported a comparison concerning direction of attack between children, cadets, juniors and seniors. They indicated that senior black belt judo athletes attacked in more directions than children judo athletes at blue and brown belt levels, suggesting an increased variability in older athletes. However, a study from the same group of authors (Calmet et al., 2006) reported that the number of direction of attacks decreased in interregional competitions compared to regional competitions for male senior judo athletes, but not for female senior judo athletes, indicating a decreased variability for the males as the competition level increased.

Therefore, although variability can be considered paramount in key judo actions, little is known about this in high-level judo athletes from different age groups, and no study analyzed the main differences in the variability of these actions in a sample of top-level judo athletes. This information can be valuable to provide directions for a better technical-tactical training organization. Thus, the main goals of the present study were to verify the differences concerning grip, actions before attacking, throwing technique, direction of attack, transition and groundwork technique variations between judo athletes from different age groups - cadet, junior and senior -, sexes and between gold, silver and bronze medalists in the World Championships. The main hypotheses of the present study were that a higher variation would be present in seniors than in cadets, and higher variation in gold medal winners than in bronze medal winners. However, no difference would be found between the junior group and the other two groups, between silver medal winners and the other medalists. Concerning the comparison between sexes no difference was expected as previous investigations (Camargo et al., 2019; Franchini et al., 2008) reported no differences between male and female athletes regarding number of throwing and groundwork techniques (Franchini et al., 2008) or for the directions of attacks (Camargo et al., 2019).

\section{Methods}

\subsection{Sample}

A total of 296 Judo World Championship medal winners had each of their matches analyzed during these competitions. For cadets only one World Championship was analyzed, as the event was conducted each two years, resulting in 8 gold, 8 silver, 16 male and 14 female bronze medal winners ( 2 athletes had no contests videos available). For junior and senior judo athletes, two World Championships were analyzed. For juniors a total of 15 gold, 15 silver and 30 bronze medal winners for each sex was investigated because there were 8 weight categories for each sex in 2018 and 7 weight categories for each sex in 2019, whereas for seniors a total of 14 gold, 14 silver and 28 bronze medal winners were analyzed ( 7 weight categories for each sex). For these athletes all scoring actions along 1282 matches were considered (including matches in which the athletes were defeated). In these matches the athletes executed 1202 scoring actions in standing position and 300 scoring actions in groundwork position. This study was approved by the local ethics committee (CAAE 13322519.2.0000.5391).

\subsection{Variables determination}

Variables pertaining to techniques (Camargo et al., 2019), directions and side of attacks (Martins et al., 2019), grip (Calmet et al., 2010), previous conditions and transition (Miarka et al., 2011; Nagai et al., 2019) were registered according to reliable and objective definitions (Miarka et al., 2011) as following:

Scoring techniques - the official scores attributed by the referee were considered, and the type of technique registered, i.e., throwing technique (nage-waza) or control techniques (katamewaza, allowed only in the groundwork combat, ne-waza). For katame-waza techniques the type was 
also determined (i.e., immobilization techniques - osaekomi-waza -, strangle techniques - shime-waza -, and elbow joint-lock techniques - kansetsu-waza). For both type of techniques, the nomenclature used by the International Judo Federation was used to define the specific technique applied by the athlete, adding a subdivision for seoi-nage (i.e., considering suwari-seoi-nage due to its quite different mechanical aspect when compared with the traditional seoi-nage). The number of different techniques used by each athlete along the competition was determined for standing and groundwork combats separately;

Direction and side of attack - this study used two directions (backward and forward) and two sides (right and left), which combined, resulted in four possibilities, i.e., left backward, left forward, right backward, and right forward, considering the athlete being thrown (uke) as reference. The number of different directions used by each athlete was determined;

Grip - grip configuration during the throwing technique scoring action, including traditional (lapel and sleeve, i.e., one hand - right or left - gripping the lapel and the other gripping the sleeve), crossed (grip the lapel and sleeve in the same side), waist control (instead of a lapel grip, the control is made on the waist of the opponent), two hands in the lapel, two hands in the sleeve, only one gripping hand in the sleeve, only one gripping hand in the lapel, and non-orthodox (grips other than those previously mentioned, including mainly two hands in the opponent's waist, opponent's back crossed grip, one hand in the lapel and the other in the waist). The number of grips used along the competition was determined for each athlete;

Conditions before attacking - the pattern of actions before executing the throwing technique was considered, including actions with the grip control for more than $5 \mathrm{~s}$, attack immediately having the grip control, attack executed during the grip dispute, counterattack (kaeshi-waza), attack immediately after opponent's attack - a form of opportunistic attack, combined attacks (renrakurenka-waza), attack with the opponent kneeling (ne-shisei). The number of different conditions before attacking was determined for each athlete.

Transition and groundwork anticipation - how the transition from the standing position to groundwork combat took place, including immediately a scoring throwing technique, after a throwing technique attempt, after an opponent's failed throwing technique, after executing a defensive action during groundwork, and opponent's conduction to the ground. The number of different actions before scoring during the groundwork combat was determined of each athlete along the competition.

The first author analyzed all the matches. This researcher has 31 years of experience with judo and 10 years of experience as judo performance analyst, having presented reliable measures for throwing techniques (ICC $=0.84$ ) and control techniques (ICC $=0.92$ ) (Moura et al., 2017). The matches were analyzed through official videos available on the official database website of the International Judo Federation (www.judobase.org). As this database provides a scoring technique tagging system there was no need to use specific performance analysis software. All scoring actions were identified, the variables above were analyzed as suggested in the investigations previously mentioned, and then notated in electronic spreadsheets for statistics analysis.

\subsection{Statistics}

Values are presented as mean and standard deviation, and 95\% confidence intervals (95\%CI). Technique (nage-waza and katame-waza), direction of attack, grip, conditions before attacking and transition variation were compared between age groups, sexes and podium positions via a three-way (age, sex and position) analysis of variance, followed by a Tukey test for unequal sample size when an analysis of variance difference was found. Significance level was set at $5 \%$. Effect sizes were determined via partial eta squared $\left(\eta^{2} \mathrm{p}\right)$ and the Cohen's classification was used as follows: 0.0099, small; 0.0588, moderate; 0.1379, large (Cohen, 1988).

\section{Results}

Table 1 presents the values for grip, actions before attack, technique and direction variations in judo World Championships medal winners of different ages and sexes. For grip variation, main effects of age $\left(\mathrm{F}_{2,270}=4.39, p=0.013, \eta^{2} \mathrm{p}=0.031\right.$, small $)$, sex $\left(\mathrm{F}_{1,270}=25.52, p<0.001, \eta^{2} \mathrm{p}=0.086\right.$, 
moderate), and position $\left(\mathrm{F}_{2,270}=3.15, p=0.013, \eta^{2} \mathrm{p}=0.044\right.$, small $)$ were found. The post hoc identified only sexes differences, with males presenting higher grip variation than females $(p<0.001)$. Additionally, a sex and age interaction effect was found $\left(\mathrm{F}_{2,270}=5.36, p=0.005, \eta^{2} \mathrm{p}=0.038\right.$, small), with senior males presenting higher grip variation than all other groups $(p<0.001$ for all female age groups comparisons, $p=0.040$ for cadet males comparison, and $p=0.005$ for junior male comparisons).

Actions before attacking differed between sexes $\left(\mathrm{F}_{1,270}=33.17, p<0.001, \eta^{2} \mathrm{p}=0.109\right.$, moderate $)$, and positions $\left(\mathrm{F}_{2,270}=6.93, p=0.001, \eta^{2} \mathrm{p}=0.049\right.$, small $)$, with males presenting higher variation than females $(p<0.001)$, and gold medal winners presenting higher variation than bronze medal winners $(p=0.004)$.

For technique variation, a main effect of sex was found $\left(\mathrm{F}_{1,270}=38.95, p<0.001, \eta^{2} \mathrm{p}=0.126\right.$, moderate), with higher variation in males compared to females $(p<0.001)$. An age and sex interaction was also revealed $\left(F_{2,270}=3.50, p=0.032, \eta^{2} \mathrm{p}=0.025\right.$, small), with female cadets presenting less variation than male cadets $(p=0.016)$, male juniors $(p=0.031)$, and male seniors $(p<0.001)$.

For direction of attack, main effects of age $\left(\mathrm{F}_{2,270}=3.32, p=0.037, \eta^{2} \mathrm{p}=0.024\right.$, small $)$ and sex $\left(\mathrm{F}_{1,270}=17.05, p<0.001, \eta_{\mathrm{p}}^{2}=0.059\right.$, moderate $)$ were observed. However, the post hoc indicated only difference between sexes, revealing that males attacked in more directions than females $(p<0.001)$.

Table 2 presents the values for transition and groundwork technique variations in judo World Championships medal winners of different ages and sexes.

For transition variation, only a main effect of position $\left(\mathrm{F}_{2,160}=9.46, p<0.001, \eta^{2} \mathrm{p}=0.106\right.$, moderate) was found, with higher values for gold medal winners compared to silver ( $p=0.002$ ) and bronze $(p=0.010)$ medalists. For groundwork technique variation, no main effects or interaction effects were observed ( $p>0.318)$.

Table 3 and 4 present the top effective techniques executed in the judo World Championships by medal winners of different ages and sexes.

Table 1. Grip, actions before attack, technique and direction variations in judo World Championships medal winners of different ages and sexes (values are presented as mean and standard deviation; values in parenthesis are $95 \%$ confidence intervals).

\begin{tabular}{|c|c|c|c|c|}
\hline Categories & Grip variation & $\begin{array}{l}\text { Actions before } \\
\text { attacking }\end{array}$ & $\begin{array}{l}\text { Technique } \\
\text { variation }\end{array}$ & $\begin{array}{l}\text { Direction } \\
\text { variation }\end{array}$ \\
\hline Female cadet gold medalists $(n=7)$ & $2.0 \pm 0.8(1.2-2.8)$ & $2.4 \pm 1.0(1.5-3.3)^{\mathrm{b}}$ & $2.3 \pm 1.3(1.1-3.4)^{\mathrm{d}}$ & $2.1 \pm 0.7(1.5-2.8)$ \\
\hline Female cadet silver medalists ( $\mathrm{n}=7$ ) & $2.1 \pm 1.1(1.2-3.1)$ & $2.1 \pm 0.9(1.3-3.0)$ & $2.0 \pm 0.8(1.2-2.8)^{\mathrm{d}}$ & $2.0 \pm 0.8(1.2-2.8)$ \\
\hline Female cadet bronze medalists $(\mathrm{n}=13$ ) & $2.1 \pm 0.9(1.6-2.6)$ & $2.2 \pm 0.7(1.7-2.6)$ & $2.5 \pm 0.9(2.0-3.1)^{\mathrm{d}}$ & $1.9 \pm 0.6(1.5-2.3)$ \\
\hline Female junior gold medalists $(n=15)$ & $3.0 \pm 1.3(1.9-4.1)$ & $3.8 \pm 0.5(3.4-4.1)^{\mathrm{b}}$ & $4.0 \pm 0.9(3.2-4.8)$ & $2.1 \pm 0.6(1.6-2.7)$ \\
\hline Female junior silver medalists $(n=14)$ & $2.4 \pm 0.9(1.6-3.1)$ & $3.1 \pm 0.8(2.4-3.8)$ & $3.4 \pm 1.2(2.4-4.4)$ & $2.0 \pm 0.8(1.4-2.6)$ \\
\hline Female junior bronze medalists $(n=29)$ & $2.4 \pm 0.9(2.0-2.9)$ & $2.6 \pm 1.3(2.0-3.3)$ & $3.2 \pm 1.6(2.4-4.0)$ & $2.4 \pm 0.9(2.0-2.9)$ \\
\hline Female senior gold medalists $(n=14)$ & $2.5 \pm 1.1(1.8-3.1)$ & $2.7 \pm 1.4(1.9-3.5)^{\mathrm{b}}$ & $2.7 \pm 1.0(2.2-3.3)$ & $2.2 \pm 0.8(1.8-2.6)$ \\
\hline Female senior silver medalists $(n=14)$ & $2.4 \pm 0.9(1.9-3.0)$ & $2.7 \pm 0.8(2.2-3.2)$ & $3.1 \pm 1.1(2.4-3.7)$ & $2.2 \pm 0.8(1.8-2.7)$ \\
\hline Female senior bronze medalists $(n=28)$ & $2.1 \pm 0.9(1.8-2.5)$ & $2.6 \pm 1.2(2.1-3.0)$ & $2.9 \pm 1.3(2.4-3.4)$ & $2.0 \pm 0.8(1.7-2.3)$ \\
\hline Male cadet gold medalists $(n=8)$ & $2.9 \pm 0.8(2.5-3.4)^{\mathrm{a}}$ & $3.2 \pm 1.1(2.6-3.8)^{\mathrm{ab}}$ & $3.7 \pm 1.4(3.0-4.5)^{\mathrm{a}}$ & $2.7 \pm 1.0(2.2-3.3)^{\mathrm{a}}$ \\
\hline Male cadet silver medalists $(n=8)$ & $2.5 \pm 1.4(1.7-3.2)^{\mathrm{a}}$ & $3.4 \pm 1.5(2.6-4.2)^{\mathrm{a}}$ & $3.1 \pm 1.4(2.3-3.9)^{\mathrm{a}}$ & $2.1 \pm 0.9(1.6-2.6)^{\mathrm{a}}$ \\
\hline Male cadet bronze medalists $(n=16)$ & $2.5 \pm 1.2(2.1-3.0)^{\mathrm{a}}$ & $2.9 \pm 1.0(2.5-3.2)^{\mathrm{a}}$ & $3.3 \pm 1.3(2.8-3.8)^{\mathrm{a}}$ & $2.6 \pm 1.0(2.2-3.0)^{\mathrm{a}}$ \\
\hline Male junior gold medalists $(n=15)$ & $2.5 \pm 1.1(1.9-3.1)^{\mathrm{a}}$ & $3.1 \pm 1.2(2.5-3.8)^{\mathrm{ab}}$ & $3.2 \pm 1.4(2.4-4.0)^{\mathrm{a}}$ & $2.4 \pm 0.9(1.8-2.9)^{\mathrm{a}}$ \\
\hline Male junior silver medalists $(n=15)$ & $1.9 \pm 0.9(1.4-2.5)^{\mathrm{a}}$ & $2.0 \pm 0.9(1.5-2.5)^{\mathrm{a}}$ & $2.1 \pm 1.0(1.5-2.6)^{\mathrm{a}}$ & $1.7 \pm 0.7(1.3-2.1)^{\mathrm{a}}$ \\
\hline Male junior bronze medalists $(n=30)$ & $2.2 \pm 1.1(1.8-2.6)^{\mathrm{a}}$ & $2.5 \pm 1.0(2.2-2.9)^{\mathrm{a}}$ & $2.8 \pm 1.2(2.3-3.3)^{\mathrm{a}}$ & $2.1 \pm 0.8(1.8-2.4)^{\mathrm{a}}$ \\
\hline Male senior gold medalists $(n=13)$ & $3.8 \pm 1.1(3.2-4.5)^{\mathrm{ac}}$ & $4.0 \pm 0.7(3.6-4.4)^{\mathrm{ab}}$ & $4.4 \pm 1.6(3.4-5.3)^{\mathrm{a}}$ & $2.8 \pm 0.8(2.3-3.3)^{a}$ \\
\hline Male senior silver medalists $(\mathrm{n}=14)$ & $3.4 \pm 1.1(2.8-4.1)^{\mathrm{ac}}$ & $3.6 \pm 0.9(3.1-4.1)^{\mathrm{a}}$ & $4.1 \pm 1.3(3.3-4.8)^{\mathrm{a}}$ & $3.1 \pm 0.5(2.8-3.3)^{\mathrm{a}}$ \\
\hline Male senior bronze medalists $(\mathrm{n}=28)$ & $3.0 \pm 1.1(2.6-3.5)^{\mathrm{ac}}$ & $3.0 \pm 1.1(2.5-3.4)^{\mathrm{a}}$ & $3.7 \pm 1.2(3.2-4.2)^{\mathrm{a}}$ & $2.8 \pm 0.8(2.5-3.0)^{\mathrm{a}}$ \\
\hline
\end{tabular}

aDifference between male and female $(p<0.001)$. ${ }^{b}$ Difference between gold and bronze medalists $(p<0.05)$. ${ }^{c}$ Higher values than all other female and male age groups $(p<0.05)$. ${ }^{d}$ Lower than all male age groups $(\mathrm{p}<0.05)$. 
Table 2. Groundwork technique and transition variations in judo World Championships medal winners of different ages and sexes (values are presented as mean and standard deviation; values in parenthesis are $95 \%$ confidence intervals).

\begin{tabular}{|c|c|c|}
\hline Categories & Transition variation & Katame-waza variation \\
\hline Female cadet gold medalists $(n=7)$ & $1.9 \pm 0.9(1.0-2.7)^{a}$ & $1.1 \pm 0.4(0.8-1.5)$ \\
\hline Female cadet silver medalists $(n=6)$ & $1.3 \pm 0.5(0.8-1.9)$ & $1.3 \pm 0.5(0.8-1.9)$ \\
\hline Female cadet bronze medalists $(n=9)$ & $1.4 \pm 0.5(1.0-1.8)$ & $1.2 \pm 0.4(0.9-1.6)$ \\
\hline Female junior gold medalists $(n=13)$ & $2.2 \pm 0.8(1.2-3.2)^{\mathrm{a}}$ & $1.2 \pm 0.4(0.6-1.8)$ \\
\hline Female junior silver medalists $(n=10)$ & $1.0 \pm 0.0(1.0-1.0)$ & $1.0 \pm 0.0(1.0-1.0)$ \\
\hline Female junior bronze medalists $(n=19)$ & $1.0 \pm 0.0(1.0-1.0)$ & $1.0 \pm 0.0(1.0-1.0)$ \\
\hline Female senior gold medalists $(n=13)$ & $1.5 \pm 0.5(1.1-1.8)^{\mathrm{a}}$ & $1.3 \pm 0.6(0.9-1.7)$ \\
\hline Female senior silver medalists $(n=13)$ & $1.3 \pm 0.7(0.8-1.8)$ & $1.2 \pm 0.4(0.9-1.5)$ \\
\hline Female senior bronze medalists $(n=16)$ & $1.3 \pm 0.5(1.0-1.5)$ & $1.1 \pm 0.3(1.0-1.3)$ \\
\hline Male cadet gold medalists $(n=5)$ & $1.4 \pm 0.5(0.9-1.8)^{\mathrm{a}}$ & $1.3 \pm 0.5(0.9-1.6)$ \\
\hline Male cadet silver medalists $(n=5)$ & $1.0 \pm 0.0(1.0-1.0)$ & $1.0 \pm 0.0(1.0-1.0)$ \\
\hline Male cadet bronze medalists $(n=5)$ & $1.4 \pm 0.8(0.8-2.0)$ & $1.3 \pm 0.7(0.8-1.8)$ \\
\hline Male junior gold medalists $(n=8)$ & $1.7 \pm 0.6(1.3-2.1)^{\mathrm{a}}$ & $1.4 \pm 0.5(1.1-1.7)$ \\
\hline Male junior silver medalists $(n=8)$ & $1.5 \pm 0.5(1.2-1.9)$ & $1.2 \pm 0.4(1.0-1.5)$ \\
\hline Male junior bronze medalists $(n=10)$ & $1.4 \pm 0.6(1.1-1.8)$ & $1.2 \pm 0.4(1.0-1.4)$ \\
\hline Male senior gold medalists $(n=5)$ & $1.6 \pm 0.5(0.9-2.3)^{\mathrm{a}}$ & $1.4 \pm 0.5(0.7-2.1)$ \\
\hline Male senior silver medalists $(n=7)$ & $1.1 \pm 0.4(0.8-1.5)$ & $1.1 \pm 0.4(0.8-1.5)$ \\
\hline Male senior bronze medalists $(n=18)$ & $1.3 \pm 0.5(1.0-1.5)$ & $1.2 \pm 0.4(1.0-1.4)$ \\
\hline
\end{tabular}

aDifference between gold and other medalists $(p<0.05)$; katame-waza $=$ control techniques.

Table 3. Top five throwing (nage-waza) and top three groundwork (katame-waza) effective techniques in judo World Championships for female medal winners of different ages (values are number of scores reached).

\begin{tabular}{|c|c|c|c|c|c|c|}
\hline $\begin{array}{l}\text { Type of } \\
\text { technique }\end{array}$ & Cadet & Scores & Junior & Scores & Senior & Scores \\
\hline \multirow{5}{*}{ Nage-waza } & sumi-otoshi & 9 & uchi-mata & 30 & uchi-mata & 27 \\
\hline & uchi-mata & 8 & o-uchi-gari & 21 & o-uchi-gari & 20 \\
\hline & o-soto-gari & 7 & o-soto-gari & 14 & o-soto-gari & 11 \\
\hline & $\begin{array}{l}\text { o-uchi-gari, and } \\
\text { suwari-seoi-nage }\end{array}$ & 6 & sumi-otoshi & 14 & harai-makikomi & 10 \\
\hline & & & tai-otoshi & 13 & sumi-otoshi & 9 \\
\hline \multirow{3}{*}{ Katame-waza } & yoko-shiho-gatame & 10 & yoko-shiho-gatame & 14 & yoko-shiho-gatame & 29 \\
\hline & $\begin{array}{c}\text { kesa-gatame, and } \\
\text { kuzure-kesa-gatame }\end{array}$ & 8 & kuzure-kesa-gatame & 11 & $\begin{array}{c}\text { kesa-gatame, and } \\
\text { kuzure-kesa-gatame }\end{array}$ & 8 \\
\hline & & & kesa-gatame & 10 & & \\
\hline
\end{tabular}

Note: suwari-seoi-nage refers to the kneeling variation of the technique seoi-nage.

Table 4. Top five throwing (nage-waza) and top three groundwork (katame-waza) effective techniques in judo World Championships for male medal winners of different ages (values are number of scores reached).

\begin{tabular}{|c|c|c|c|c|c|c|}
\hline $\begin{array}{c}\text { Type of } \\
\text { technique }\end{array}$ & Cadet & Scores & Junior & Scores & Senior & Scores \\
\hline \multirow{4}{*}{ Nage-waza } & tani-otoshi & 9 & uchi-mata & 29 & sumi-otoshi & 39 \\
\hline & o-uchi-gari & 8 & sumi-otoshi & 25 & uchi-mata & 34 \\
\hline & \multirow{2}{*}{$\begin{array}{l}\text { harai-makikomi, kata- } \\
\text { guruma, ko-uchi- } \\
\text { makikomi, soto- } \\
\text { makikomi, and sumi- } \\
\text { gaeshi }\end{array}$} & \multirow[b]{2}{*}{7} & kata-guruma & 20 & suwari-seoi-nage & 25 \\
\hline & & & $\begin{array}{c}\text { o-soto-gari, and o- } \\
\text { uchi-gari }\end{array}$ & 17 & $\begin{array}{c}\text { o-soto-gari, and o- } \\
\text { uchi-gari }\end{array}$ & 18 \\
\hline \multirow[b]{3}{*}{ Katame-waza } & okuri-eri-jime & 5 & yoko-shiho-gatame & 11 & kuzure-kesa-gatame & 8 \\
\hline & kata-gatame & 4 & kesa-gatame & 5 & $\begin{array}{l}\text { kuzure-kami-shiho- } \\
\text { gatame }\end{array}$ & 7 \\
\hline & $\begin{array}{c}\text { kesa-gatame, kuzure- } \\
\text { kesa-gatame, and } \\
\text { yoko-shiho-gatame }\end{array}$ & 3 & $\begin{array}{c}\text { kata-gatame, } \\
\text { kuzure-kesa-gatame, } \\
\text { sode-guruma-jime, } \\
\text { and kami-shiho- } \\
\text { gatame }\end{array}$ & 3 & okuri-eri-jime & 6 \\
\hline
\end{tabular}

Note: suwari-seoi-nage refers to the kneeling variation of the technique seoi-nage. 


\section{Discussion}

The main findings partially confirmed the hypotheses established, i.e., as higher variation was observed for gold medal winners for grip, actions before attack compared to bronze medalists, whereas transition variation was greater for gold medal winners compared to the other medalists. However, no differences were found between age groups, except when interacting with sex, as a lower technique variation was observed in female cadets compared to all other male age groups. Additionally, less variation was observed in females compared to males for grip, actions before attacking, technique variation and direction of attacks.

As only tendencies of differences were found between age groups, it seems that at high-level (i.e., World Championship level) athletes already present a variability of actions at cadet and junior ages similar to those of seniors. This is a relevant finding, because low variability could be interpreted as a signal of early specialization, which is frequently suggested as a problem for athletes competing in judo (Julio et al., 2011). Although competitive technical improvement is a process that evolves slowly (Calmet \& Ahmaidi, 2004), athletes engaged in high-performance training programs should be encouraged to continually expand their technical-tactical repertoire and develop less predictable systems of attack.

The higher variation of grip configuration for gold medalists compared to bronze medal winners supports the findings of Calmet et al. (2010), that indicated that a more complex grip configuration is observed in higher level athletes compared to intermediate athletes and beginners. Moreover, our finding adds a relevant information because it indicates that the process of a more complex grip dispute strategy - herein inferred from the grip variation - is still in place at the highest competitive level. Therefore, coaches and judo athletes should constantly invest time and efforts to improve their grip. However, a study investigating the training processes of Olympic judo athletes reported that both medal winners and non-medal winners spent only 10-13 minutes per session exclusively practicing grip dispute (Franchini \& Takito, 2014).

A higher variation of actions before attacking for gold medalists compared to bronze medalists can be explained by the potential utilization of this approach in the feint process, which would induce the so called psychological refractory period, resulting in a slowed response to the throwing technique stimulus because the first stimulus (i.e., the action executed before the attack) is still being processed by the opponent (Schmidt \& Lee, 2020). Consequently, coaches should encourage judo athletes to focus on creating different and diverse actions to connect to their main throwing technique. This approach should include grip variation, the use of other judo techniques, displacements in different directions, unbalance actions before the main technique, and opportunistic attacks taking advantage of ineffective actions by opponents.

The transition from standing combat to groundwork was the only variable that was different between gold and silver medal winners, as well as different between gold and bronze winners. The relevance of this phase was reported recently (Nagai et al., 2019), and our finding indicates that the variation in this phase is a key element for success at World Championship level. Therefore, coaches should create a structure of practice where different transition approaches should be used, including variations of rhythm (e.g., immediately after the throwing technique execution, as a consecutive link, or as a progression in the groundwork), position of the opponent (e.g., turtle, supine, prone, halfguard, besides, guard, standing and seated) and type of groundwork technique (immobilization, strangle and elbow joint-lock).

The differences observed between male and female judo athletes concerning males for grip, actions before attacking, throwing technique and direction of attacks variation are harder to explain. However, the fact that a lower number of females engage in combat sports in general and in judo specifically (Franchini et al., 2020; Miarka et al., 2011), can be a possible reason. A lower number of competitors may result in lesser need of variation to achieve success. However, as these aspects are important for success in judo, female judo athletes should also be encouraged to increase their variability. Indeed, a previous study (Franchini et al., 2008) demonstrated that super-elite female judo athletes had a higher number of throwing techniques and higher number of attacks in different directions compared to elite female judo athletes. 
For groundwork technique variation, no main effects or interaction effects were observed, which confirms the findings from Franchini et al. (2008) that reported a high specialized approach of judo athletes concerning groundwork combat. However, with the recent changes in judo rules, allowing a higher time for combat in the ground, it is likely that athletes will need more variation to be successful in this phase of the combat; even though this can take some time.

Concerning the most used techniques, for female judo athletes four throwing techniques appeared among the most used for all age groups (i.e., uchi-mata, o-uchi-gari, o-soto-gari, and sumiotoshi), whereas only one (i.e., $o$-uchi-gari) of the top five used throwing techniques was common for all male judo age groups. For groundwork techniques, females also presented more similarity among age groups (i.e., yoko-shiho-gatame, kesa-gatame, and kuzure-kesa-gatame) were the most used in all age groups, whereas only one technique (i.e., kuzure-kesa-gatame) was among the most groundwork techniques for male judo athletes for all age groups. Understanding the characteristics of successful throwing and groundwork techniques execution by World Championships medal winners can help coaches to improve the system of attacks and defense of judo athletes preparing to achieve this level (Camargo et al., 2019).

Some limitations in this investigation must be considered. Perhaps the fact that these medalists are top-level athletes makes it difficult to apply this results in other groups. However, one of the goals of coaches involved in high-level training should be to develop this level of technical variation in athletes seeking world-class performance. Another limitation may be the number and type of competitions analyzed, suggesting that future research should analyze these variables in a greater number of competitions in the IJF world circuit for Cadets, Juniors, and Seniors categories.

\section{Conclusion}

The findings of the present study indicated that gold medal winners in World Championships presented higher variation for grip, actions before attack compared to bronze medalists, and higher transition variation compared to the other medalists. However, there were no differences between age groups, except when interacting with sex, suggesting that variation is well-developed even for cadet athletes achieving this competitive level. Additionally, females presented less variation than males for grip, actions before attacking, technique variation and direction of attacks, which may be attributed to the smaller number of females engaged in competitive judo.

\section{Funding}

The second author is supported by the Conselho Nacional de Desenvolvimento Científico e Tecnológico (CNPq) under grant number 301003/2019-0.

\section{References}

Calmet, M., \& Ahmaidi, S. (2004). Survey of advantages obtained by judoka in competition by level of practice. Perceptual and Motor Skills, 99(1), 284-290. doi: 10.2466/pms.99.1.284-290

Calmet, M., Miarka, B., \& Franchini, E. (2010). Modeling of grasps in judo contests. International Journal of Performance Analysis in Sport, 10(3), 229-240. doi: $10.1080 / 24748668.2010 .11868518$

Calmet, M., Trezel, N., \& Ahmaidi, S. (2006). Survey of system of attack by judoka in regional and interregional matches. Perceptual Motor Skills, 103(3), 835-840. doi: 10.2466/pms.103.3.835$\underline{840}$

Camargo, R. G., Guerra, G. M., Rosa, R. L., Calmet, M., Takito, M. Y., \& Franchini, E. (2019). Attack side and direction during the 2017 Judo World Championship. Sport Sciences for Health, 15, 477 480. doi: $10.1007 / \mathrm{s} 11332-019-00540-6$

Cohen, J. (1988). Statistical power analysis for the behavioral sciences. Lawrence Earlbaum Associated Hillsdale.

Franchini, E., Artioli, G. G., \& Brito, C. J. (2013). Judo combat: time-motion analysis and physiology. International Journal of Performance Analysis in Sport, 13(3), 624-641. doi: $\underline{10.1080 / 24748668.2013 .11868676}$

Franchini, E., Fukuda, D. H., \& Lopes-Silva, J. P. (2020). Tracking 25 years of judo results from the World Championships and Olympic Games: Age and competitive achievement. Journal of Sports Sciences, 38(13), 1531-1538. doi: 10.1080/02640414.2020.1747265 
Franchini, E., \& Takito, M. Y. (2014). Olympic preparation in Brazilian judo athletes: description and perceived relevance of training practices. Journal of Strength and Conditioning Research, 28(6), 1606-1612. doi: $10.1519 /$ isc. 0000000000000300

Franchini, E., Sterkowicz, S., Meira, C. M., Gomes, F. R., \& Tani, G. (2008). Technical variation in a sample of high level judo players. Perceptual and Motor Skills, 106(3), 859-869. doi: $10.2466 /$ pms.106.3.859-869

Julio, U. F., Takito, M. Y., Mazzei, L., Miarka, B., Sterkowicz, S, \& Franchini, E. (2011). Tracking 10-year competitive winning performance of judo athletes across age groups. Perceptual and Motor Skills, 113(1), 139-149. doi: 10.2466/05.10.11.pms.113.4.139-149

Martins, F. P., Souza, L. S. D. P., Campos, R. P., Bromley, S. J., Takito, M. Y., \& Franchini, E. (2019). Techniques utilised at 2017 Judo Wolrd Championship and theis classification: comparisons between sexes, weight categories, winners and non-winners. Ido Movement for Culture, 19(1), 58-65. doi: 10.14589/ido.19.1.6

Miarka, B., Marques, J. B., \& Franchini, E. (2011). Reinterpreting the history of women's judo in Japan. International Journal of the History of Sport, 28(7), 1016-1029. doi: $10.1080 / 09523367.2011 .563633$

Moura, C., Agostinho, M. F., \& Franchini, E. (2017). Pacing in judo: inter and intra-observer objectivity of temporal and technical variables. Annals of Simpósio Internacional de Iniciação Científica e Tecnologia da USP. São Paulo. Available at https://uspdigital.usp.br/siicusp/siicPublicacao.jsp?codmnu=7210

Nagai, S., Takito, M. Y., Calmet, M., Pierantozzi, E., \& Franchini, E. (2019). Successful transition to groundwork combat during Junior and Senior Judo World Championships. International Journal of Performance Analysis in Sport, 19(2), 206-215. doi: $\underline{10.1080 / 24748668.2019 .1585739}$

Schimdt, R. A., \& Lee, T. D. (2020). Motor learning and performance: from principles to application. Human Kinetics.

\section{Author's biographical data}

Marcus Fábio Agostinho (Brazil). Master in Sciences. Professor in Physical Education undergraduate course at Faculdade Lusófona de São Paulo. Member of Martial Arts and Combat Sports Research Group. Brazilian female cadet judo team coach. Judo black belt 2nd dan. E-mail: maagostinho@hotmail.com

Emerson Franchini (Brazil). Associate Professor, School of Physical Education and Sport, University of São Paulo, Brazil, Coordinator of the Martial Arts and Combat Sports Research Group, Consultant of Judo Olympic and World Championship's medal winners, Judo black belt 2nd dan. E-mail: emersonfranchini@hotmail.com 